\title{
PENGARUH KOMBINASI TEPUNG ROTI AFKIR DAN \\ TEPUNG KULIT MANGGIS SEBAGAI SUBSTITUSI JAGUNG DALAM RANSUM ITIK CIHATEUP TERHADAP PERFORMAN PERTUMBUHAN DAN INCOME OVER FEED COST
}

\author{
A. KUSMAYADI \\ 1Program Studi Peternakan, Fakultas Pertanian Universitas Perjuangan \\ Pembela Tanah Air No. 177 Tawang - 46115, Jawa Barat, Indonesia. \\ Email : andrikusmayadi1@gmail.com
}

\begin{abstract}
The purpose of this study is to examine the effect of the level of Rejected Bread Flour (RBF) and Mangosteen Flour (MF) as a substitute for corn on growth performance and Income Over Feed Cost (IOFC) of Cihateup ducks. The sixty-three ducks were divided randomly into 7 feed treatment groups, namely: control (R0), feed with the addition of $10 \%$ RBF corn substitute $+1 \% M F(R 1 A)$, feed with the addition of $10 \%$ RBF corn substitute $+2 \%$ MF (R1B), feed with the addition of $20 \%$ RBF corn substitute $+1 \%$ MF (R2A), feed with the addition of $20 \%$ RBF corn substitute $+2 \%$ MF (R2B), feed with the addition of $30 \%$ RBF corn substitute $+1 \% M F(R 3 A)$ and feed with the addition of $30 \%$ RBF corn substitute $+2 \% M F$ (R3B). The variables observed were final body weight, body weight gain, feed consumption, feed conversion and IOFC. The study used a completely randomized design, if significantly different was further tested by the DMRT method. The results showed that the feed treatment had a significant effect $(P<0.05)$ on final body weight, body weight gain and IOFC. The R2B treatment containing $20 \% R B F$ and $1 \%$ MF had the best growth performance. The treatment of R1B containing $10 \% R B F$ and $2 \%$ MF resulted in higher IOFC values compared to other treatments. Thus, giving 20\% RBF and $2 \%$ MF is recommended to improve growth performance and giving 10\% RBF and $2 \%$ MF can be applied to increase IOFC values.
\end{abstract}

Keywords: IOFC, Cihateup duck, performance, mangosteen peel, rejected bread

\section{PENDAHULUAN}

Itik Cihateup sebagai itik pedaging memiliki permasalahan yang lebih kompleks dibandingkan dengan ayam pedaging terutama pertumbuhan yang lambat dengan efisiensi pakan yang boros. Pakan merupakan bahan baku utama yang perlu diperhatikan dalam usaha peternakan unggas. Bahan baku pakan unggas masih sangat bergantung pada jagung sebagai sumber energi utama. Peternak unggas biasa menggunakan jagung sampai $50 \%$ dari total ransum yang diformulasikannya. Hal ini menjadi masalah serius bagi peternak unggas mengingat harga jagung yang semakin meningkat sehingga perlu dicari solusi alternatif untuk mengganti jagung dengan bahan lain yang memiliki harga murah dan tidak bersaing sebagai pangan manusia.

Salah satu bahan pakan alternatif yang dapat digunakan sebagai pakan unggas yaitu roti afkir. Roti afkir adalah roti yang telah lewat batas waktu konsumsi sehingga tidak layak dikonsumsi oleh manusia (Winarti, 2017) sehingga memiliki harga jual yang rendah. Roti afkir yang merupakan limbah tersebut dapat dijadikan tepung sebagai sumber energi pada ternak unggas mengingat kandungan karbohidratnya sebagai sumber energi masih tinggi yaitu mencapai 56,6\% (Gaol et al., 2015). Selain karbohidrat, tepung roti afkir juga mengandung protein sebesar 10,25\%; lemak 13,42\%; serat kasar 12,04; air 6,91\%, dan abu 0,80\% (Gaol et al., 2015), kalsium $0,07 \%$; fosfor $0,019 \%$, air $6,91 \%$ dan abu 0,80\% serta Energi Bruto $4217 \mathrm{kkal} / \mathrm{kg}$ (Widjastuti dan Sujana, 2009).

Penggunaan tepung roti afkir sebagai substitusi jagung sampai level 30\% berpengaruh signifikan terhadap efisiensi pakan dan income over feed dan chick cost (Widjastuti dan Sujana,2009). Hal yang sama dilaporkan oleh Hidayatullah et al. (2014) bahwa penggunaan tepung roti afkir sampai level 30\% memiliki energi 
metabolis ransum yang cukup baik yaitu mencapai $30 \%$ dan berperan dalam menunjang pertumbuhan ternak. Penerapan tepung roti afkir akan dikombinasikan dengan tepung kulit manggis untuk menghasilkan pengaruh yang lebih signifikan terhadap kinerja pertumbuhan. Pemanfaatan tepung kulit manggis sebagai imbuhan pakan secara nyata mampu memperbaiki pertambahan bobot badan, konversi pakan dan konsumsi pakan dibandingkan kontrol (Kusmayadi et al., 2019). Pada penelitian ini akan dikaji pengaruh tepung roti afkir yang dikombinasikan dengan tepung kulit manggis terhadap kinerja pertumbuhan dan income over feed and chick cost.

\section{MATERI DAN METODE}

Materi yang digunakan dalam penelitian ini adalah 63 ekor DOD itik Cihateup unsexing. Roti afkir yang didapatkan dari Pasar Rajapolah, Kabupaten Tasikmalaya. Kandang yang digunakan dalam penelitian ini adalah kandang metabolis sebanyak 18 buah masing-masing berisi 5 ekor itik dengan ukuran 80x8x070 cm. Bahan pakan yang digunakan pada penelitian ini tersaji pada Tabel 1.

Tabel 1. Komposisi bahan pakan dan kandungan nutrisi ransum.

\begin{tabular}{lcc}
\hline \multicolumn{1}{c}{ Uraian } & Starter (\%) & Grower $(\%)$ \\
\hline Jagung & 45,00 & 55,00 \\
Bungkil kedelai & 21,50 & 16,00 \\
Dedak & 5,00 & 9,00 \\
Tepun ikan & 3,00 & 3,00 \\
Minyak & 3,00 & 1,00 \\
Garam & 0,35 & 0,35 \\
Kapur & 1,00 & 1,00 \\
Premix & 0,50 & 0,50 \\
Lisin & 0,10 & 0,10 \\
Metionin & 0,10 & 0,10 \\
Kandungan nutrisi & & \\
Protein kasar (\%) & 18,35 & 16,21 \\
Lemak kasar (\%) & 10,87 & 10,15 \\
Serat kasar (\%) & 6,67 & 7,42 \\
BETN (\%) & 51,05 & 53,11 \\
Energi (kkal/kg) & 2.867 & 2.885 \\
Ca (\%) & 0,80 & 0,80 \\
P (\%) & 0,35 & 0,35 \\
\hline
\end{tabular}

Pembuatan Tepung Roti Afkir

1. Roti afkir dikumpulkan dari kios penjual roti di Pasar Rajapolah, Tasikmalaya

2. Roti dipotong sampai ukuran tertentu

3. Roti dikeringkan menggunakan oven dengan suhu $70^{\circ} \mathrm{C}$ selama 30 menit

4. Roti digiling menggunakan mesin penepung beras

5. Tepung roti afkir diayak menggunakan saringan

6. Tepung roti disimpan pada wadah tertutup.

\section{Prosedur Percobaan}

Penelitian dilakukan dengan mengamati keenam perlakuan pakan yaitu :

R0 (100\% Ransum basal tanpa perlakuan TRA dan TKM),

R1 (Pakan dengan penambahan TRA 10\% pengganti jagung $+2 \% \mathrm{TKM}$ ),

R2 (Pakan dengan penambahan TRA 20\% pengganti jagung $+2 \%$ TKM), 
R3 (Pakan dengan penambahan TRA 30\% pengganti jagung $+2 \% \mathrm{TKM}$ ),

R4 (Pakan dengan penambahan TRA 40\% pengganti jagung $+2 \% \mathrm{TKM})$,

R5 (Pakan dengan penambahan TRA 50\% pengganti jagung $+2 \% \mathrm{TKM})$.

\section{Variabel yang Diamati}

1. Kinerja Pertumbuhan (Bobot badan, pertambahan bobot badan, konsumsi pakan dan konversi pakan)

\section{Income Over Feed Cost (IOFC)}

\section{Analisis Data}

Data dianalisis menggunakan rancangan acak lengkap pola searah, apabila terdapat perbedaan nyata dilanjutkan dengan uji Duncan.

\section{HASIL DAN PEMBAHASAN}

Hasil uji performan itik Cihateup yang mendapatkan suplementasi TRA dan TKM pada ransum tersaji pada Tabel 2.

Tabel 2. Performan pertumbuhan itik Cihateup hasil penelitian

\begin{tabular}{ccccc}
\hline Perlakuan & $\begin{array}{c}\text { Bobot badan akhir } \\
(\mathrm{g})^{*}\end{array}$ & $\begin{array}{c}\text { PBB } \\
(\mathrm{g})^{*}\end{array}$ & $\begin{array}{c}\text { Konsumsi pakan } \\
(\mathrm{g})^{\mathrm{ns}}\end{array}$ & $\begin{array}{c}\text { Konversi } \\
\text { Pakan }^{\mathrm{ns}}\end{array}$ \\
\hline R0 & $1.225,75 \pm 40,51^{\mathrm{b}}$ & $696,50 \pm 40,80^{\mathrm{b}}$ & $4.176,50 \pm 30,78$ & $6,01 \pm 0,39$ \\
R1A & $1.195,75 \pm 44,54^{\mathrm{b}}$ & $689,25 \pm 22,69^{\mathrm{a}}$ & $4.148,25 \pm 39,05$ & $6,02 \pm 0,21$ \\
R1B & $1.211,50 \pm 28,38^{\mathrm{b}}$ & $702,50 \pm 38,61^{\mathrm{b}}$ & $4.170,50 \pm 35,99$ & $5,95 \pm 0,31$ \\
R2A & $1.214,25 \pm 60,62^{\mathrm{b}}$ & $685,50 \pm 22,11^{\mathrm{a}}$ & $4.149,25 \pm 44,27$ & $6,06 \pm 0,17$ \\
R2B & $1.223,00 \pm 54,74^{\mathrm{b}}$ & $697,50 \pm 33,36^{\mathrm{b}}$ & $4.166,00 \pm 28,17$ & $5,98 \pm 0,26$ \\
R3A & $1.166,25 \pm 77,22^{\mathrm{a}}$ & $667,50 \pm 43,49^{\mathrm{a}}$ & $4.056,00 \pm 56,08$ & $6,09 \pm 0,32$ \\
R3B & $1.182,50 \pm 65,08^{\mathrm{a}}$ & $678,00 \pm 50,43^{\mathrm{a}}$ & $4.069,25 \pm 71,55$ & $6,02 \pm 0,35$ \\
\hline
\end{tabular}

Ket : R0 (Pakan tanpa perlakuan), R1A (Pakan dengan penambahan TRA 10\% pengganti jagung + 1\% TKM), R1B (Pakan dengan penambahan TRA 10\% pengganti jagung + 2\% TKM), R2A (Pakan dengan penambahan TRA 20\% pengganti jagung + 1\% TKM), R2B (Pakan dengan penambahan TRA 20\% pengganti jagung + 2\% TKM), R3A (Pakan dengan penambahan TRA 30\% pengganti jagung $+1 \%$ TKM), dan R3B (Pakan dengan penambahan TRA $30 \%$ pengganti jagung $+2 \%$ TKM). *Superskrip yang berbeda menunjukkan perbedaan yang nyata $(\mathrm{P}<0.05)$ ns non-signifikan.

Parameter yang diuji pada penelitian ini yaitu bobot badan akhir, pertambahan bobot badan, konsumsi pakan dan konversi pakan. Beberapa parameter yang diukur, perlakuan pakan berpengaruh nyata $(\mathrm{P}<0,05)$ terhadap bobot badan akhir dan PBB sementara pada parameter konsumsi dan konversi pakan tidak berpengaruh nyata $(P>0,05)$. Nilai bobot badan akhir hasil penelitian secara berturut-turut yaitu $1.225,75 \pm 40,51$; $1.195,75 \pm 44,54 ; 1.211,50 \pm 28,38$; 1.214,25 $\pm 60,62 ; 1.223,00 \pm 54,74$; $1.166,25 \pm 77,22$ dan $1.182,50 \pm 65,08$ (g).

Nilai bobot badan akhir perlakuan TRA dan TKM memiliki bobot yang lebih rendah dibandingkan perlakuan kontrol. Hasil ini sesuai dengan penelitian Kouhkan et al. (2003) yang melaporkan bahwa penggunan tepung limbah roti memiliki bobot badan yang lebih rendah dibandingkan kontrol. Hal ini berkaitan dengan komposisi pakan yang dimiliki perlakuan kontrol dan perlakuan penelitian berbeda. Perlakuan kontrol yang tidak mengandung limbah tepung roti memiliki performan pertumbuhan yang lebih baik dibandingkan perlakuan TRA (Oke, 2013).

Berdasarkan uji statistik perlakuan pakan R1 dan R2 memiliki bobot dan PBB yang mendekati perlakuan kontrol. Kondisi ini menunjukkan bahwa perlakuan pakan TRA yang dikombinasikan dengan TKM memiliki dampak positif terhadap perbaikan bobot badan akhir dan PBB. Hal ini disebabkan oleh sifat TRA dan TKM yang dapat meningkatkan palatabilitas. TRA mengandung komposisi susu dan TKM 
mengandung xanton yang mempunyai kemampuan meningkatkan nafsu makan ternak. Hasil ini sesuai dengan penelitian Widjastuti dan Sujana (2009) bahwa pemberian tepung limbah roti dalam ransum broiler mampu meningkatkan palatabilitas karena mengandung laktosa yang mampu meningkatkan populasi bakteri probiotik sehingga daya cerna meningkat. Selain itu, tepung limbah roti mengandung sumber energi karena mengandung energi yang cukup tinggi dengan tingkat kecernaannya lebih baik dibandingkan dedak padi (Chalimi et al., 2010). Penggunaan TRA sampai level 30\% memiliki dampak positif dalam meningkatkan bobot badan ternak karena masih dapat direspons dengan baik oleh ternak.

Palapol et al. (2009) melaporkan bahwa kulit manggis memiliki dampak positif terhadap kinerja pertumbuhan broiler termasuk pertambahan bobot badan. Kusmayadi et al. (2019) melaporkan bahwa penambahan tepung kulit manggis secara tunggal maupun yang dikombinasikan dengan kunyit pada ransum itik Cihateup memiliki dampak signifikan terhadap bobot badan akhir dan pertambahan bobot badan. Hal tersebut terjadi karena kulit manggis berperan dalam menjaga keseimbangan mikroflora usus sehingga memiliki korelasi positif dengan absorpsi nutrien yang akan berdampak pada pertambahan bobot badan yang signifikan.

Parameter konsumsi dan konversi pakan, pemberian TRA dan TKM memiliki perbedaan yang tidak signifikan $(\mathrm{P}>0,05)$. Nilai rataan konsumsi pakan hasil perlakuan pakan secara berturutturut yaitu 4.176,50+30,78; 4.148,25+39,05; $4.170,50+35,99$;

$4.166,00+28,17$

$4.149,25+44,27$

$4.069,25+71,55$

$4.056,00+56,08$ dan

menunjukkan (g). Kondisi ini menunjukkan bahwa semakin tinggi penggunaan TRA, konsumsi pakan cenderung menurun. Penurunan konsumsi pakan ini dapat disebabkan oleh kandungan lemak kasar pada TRA yang relatif tinggi karena semakin tinggi pemberian TRA semakin tinggi pula kandungan lemak kasar pada pakan perlakuan itik pedaging hibrida. Hal ini disebabkan kandungan lemak kasar yang tinggi mengakibatkan pakan akan cepat rusak dan menimbukan bau tidak sedap (tengik) sehingga palatabilitas ternak pada pakan yang mengandung TRA menjadi menurun (Hidayatullah et al., 2016). Palatabilitas ternak sangat dipengaruhi oleh kualitas dan komposisi pakan dimana palatabilitas ternak akan meningkat ketika diberikan pakan berkualitas baik dengan komposisi yang seimbang (Parakkasi, 1990). Ternak akan cenderung memiliki palatabilitas yang rendah pada pakan yang berbau tengik sehingga konsumsi pakan menjadi turun.

Pemberian TKM pada dosis 2\% memberikan dampak positif terhadap penurunan konversi pakan. Kondisi ini menunjukkan bahwa TKM berkontribusi memperbaiki konsumsi dan konversi pakan. TKM mengandung senyawa xanton yang berperan dalam mengatur jumlah asupan pakan, mempengaruhi mikroflora untuk mengurangi aktivitas bakteri pathogen dalam menyerap nutrisi pakan. Toghyani et al. (2009) melaporkan bahwa senyawa bioaktif pada tanaman herbal mampu meningkatkan rangsangan nafsu dan asupan pakan, peningkatan seksresi enzim pencernaan endogen, aktivasi respon imun, antioksidan dan antimikroba. Dengan peranan ini maka nutrisi pakan mampu dimanfaatkan dan diolah menjadi pangan (daging) secara lebih efektif.

Rataan konversi pakan hasil penelitian secara berurutan yaitu 6,01+0,39; $6,02+0,21 ; 5,95+0,31 ; 6,06+0,17 ; 5,98+0,26$; $6,09+0,32$; dan 6,02+0,35. Nilai konversi pakan pada penelitian ini cenderung meningkat seiring dengan pemberian TRA yang semakin tinggi. Hasil ini sesuai dengan penelitian Hidayatullah et al. (2016) bahwa penggunaan tepung limbah roti sebagai pengganti sebagian jagung memberikan perbedaan yang tidak nyata 
$(\mathrm{P}>0,05)$ terhadap konversi pakan. Hal ini diduga disebabkan komposisi ransum antar perlakuan mengandung jagung dan TRA dalam bentuk tepung. Sebagian besar bahan baku roti yaitu tepung yang berasal dari tepung terigu yang mengandung tepung jagung, gandum dan ubi. Selain itu, kandungan karbohidrat dan protein yang dimiliki oleh jagung dan TRA hampir sama sehingga menyebabkan respon tubuh ternak terhadap daya cerna pakan sama sehingga dalam mengkonversi pakan menjadi bobot badan tidak berbeda. Perlakuan pakan berpengaruh nyata $(\mathrm{P}<0,05)$ terhadap nilai IOFC itik Cihateup sebagaimana tersaji pada Tabel 3.

Tabel 3. Nilai IOFC itik Cihateup hasil penelitian

\begin{tabular}{ccccc}
\hline Perlakuan & $\begin{array}{c}\text { Bobot panen } \\
(\mathrm{g})^{\mathrm{ns}}\end{array}$ & $\begin{array}{c}\text { Pendapatan } \\
(\mathrm{Rp})^{\mathrm{ns}}\end{array}$ & $\begin{array}{c}\text { Biaya pakan } \\
(\mathrm{Rp})^{\mathrm{ns}}\end{array}$ & $\begin{array}{c}\text { IOFC }^{*} \\
(\mathrm{Rp})\end{array}$ \\
\hline R0 & $1.225,75$ & $28.192,25$ & $16.706,00$ & $11.486,25^{\mathrm{b}}$ \\
R1A & $1.195,75$ & $27.502,25$ & $16.593,00$ & $10.909,25^{\mathrm{a}}$ \\
R1B & $1.211,50$ & $27.864,50$ & $16.682,00$ & $11.182,50^{\mathrm{a}}$ \\
R2A & $1.214,25$ & $27.927,75$ & $16.597,00$ & $11.330,75^{\mathrm{a}}$ \\
R2B & $1.223,00$ & $28.129,00$ & $16.664,00$ & $11.465,00^{\mathrm{b}}$ \\
R3A & $1.166,25$ & $26.823,75$ & $16.224,00$ & $10.599,75^{\mathrm{a}}$ \\
R3B & $1.182,50$ & $27.197,50$ & $16.277,00$ & $10.920,50^{\mathrm{a}}$ \\
\hline
\end{tabular}

Ket: R0 (Pakan tanpa perlakuan), R1A (Pakan dengan penambahan TRA 10\% pengganti jagung + 1\% TKM), R1B (Pakan dengan penambahan TRA 10\% pengganti jagung + 2\% TKM), R2A (Pakan dengan penambahan TRA 20\% pengganti jagung + 1\% TKM), R2B (Pakan dengan penambahan TRA 20\% pengganti jagung $+2 \%$ TKM), R3A (Pakan dengan penambahan TRA $30 \%$ pengganti jagung $+1 \%$ TKM), dan R3B (Pakan dengan penambahan TRA $30 \%$ pengganti jagung $+2 \%$ TKM).

*Superskrip yang berbeda menunjukkan perbedaan yang nyata $(\mathrm{P}<0.05)$

ns non-signifikan.

Nilai IOFC hasil penelitian secara berturut-turut yaitu sebagai berikut: $11.486,25 ; 10.909,25$; 11.182,50; 11.330,75; $11.465,00 ; \quad 10.599,75$ dan $10.920,50$ (Rupiah). Data ini menunjukkan bahwa nilai IOFC pakan kontrol (R0) jauh lebih tinggi dibandingkan dengan perlakuan pakan yang mengandung TRA dan TKM. Nilai IOFC ditentukan dengan hasil penjualan ternak yang sangat dipengaruhi oleh bobot badan akhir. Dengan demikian, semakin tinggi nilai IOFC akan semakin baik karena menunjukkan tingginya tingkat pendapatan dari hasil penjualan ternak (Rasyaf, 2005). Nilai IOFC diperoleh dari hasil selisih antara pendapatan dari hasil penjualan itik dengan besaran biaya ransum yang dikonsumsi ternak selama penelitian. Semakin meningkatnya konsumsi ransum maka akan menyebabkan biaya pengeluaran untuk pembelian pakan semakin meningkat.

Biaya pakan pada ternak yang mendapatkan perlakuan TRA jauh lebih rendah dibandingkan dengan biaya pakan pada perlakuan kontrol (Tabel 3). Sebaliknya, nilai akhir IOFC pakan kontrol lebih tinggi dibandingkan perlakuan lainnya karena memiliki nilai bobot badan panen serta pendapatan yang lebih besar. Hal ini dikarenakan pendapatan hasil penjualan itik sangat ditentukan oleh besaran bobot badan panen. Perlakuan pakan yang mengandung TRA dan TKM dengan dosis berbeda yang memiliki nilai yang cukup signifikan. Ternak yang mendapatkan suplementasi 2\% TKM memiliki nilai IOFC yang lebih tinggi dibandingkan ternak yang mendapatkan perlakuan 1\% TKM. Hal ini disebabkan TKM dosis 2\% mengandung senyawa bioaktif xanton 
yang lebih tinggi dibandingkan perlakuan $1 \%$ TKM. Senyawa xanton tersebut memberikan kontribusi langsung terhadap peningkatan bobot badan itik.

\section{KESIMPULAN}

Perlakuan pakan R2B yang mengandung 10\% TRA dan 2\% TKM menunjukkan dampak yang baik terhadap performan pertumbuhan ternak disertai dengan nilai IOFC yang mendekati perlakuan kontrol.

\section{DAFTAR PUSTAKA}

Chalimi, K., A.Rochim, E.Purbowati, Soedarsono, E.Rianto, dan A.Purnomoadi. 2010. Kelayakan roti sisa pasar sebagai pakan alternatif berdasar pemanfaatan kecernaan energi dan parameter darah pada sapi Peranakan Ongole. Prosiding Semnas Teknologi Peternakan dan Veteriner: 100-106.

Gaol, E.L.S., S. Lisnawaty, dan Y.Iis. 2015. Substitusi Ransum Jadi dengan Roti Afkir Terhadap Performa Burung Puyuh (Coturnix coturnix japonica) Umur Starter Sampai Awal Bertelur. Junal Ilmu Hewani Tropika. 4 (2): 61-65.

Hidayatullah,M.F., H.I.Djunaidi dan H. Natsir. 2016. Efek Penggunaan Tepung Limbah Roti Tawar sebagai Pengganti Jagung terhadap Penampilan Produksi Itik Hibrida.Jurnal Universitas Brawijaya: 1-7.

Kouhkan, M.R., H. Kermanshahi and F. Eftekhari. 2003. The effect of natural zeolite and bakery waste on performance and serum parameters of broiler chickens. In: Annual Meeting of the British Society of Animal Science, York. p. 178.

Kusmayadi, A.,K.R. Bachtiar dan C.H. Prayitno. 2019. The effects of mangosteen peel (Garcinia mangostana L.) and Turmeric (Curcuma domestica Val) flour dietary supplementation on the growth performance, lipid profile, and abdominal fat content in Cihateup ducks. Veterinary World. 12(3):402-408.
Oke, O.S. 2013. Utilization of Bread Waste Meal as Replacement for Maize in Diets for Broiler Chickens. Journal of Poverty, Investment and Development. 1: 71-75.

Palapol, Y., S. Ketsa, D.Stevenson, J.M. Cooney, A.C. Allan and Ferguson, I.B. 2009. Colour development and quality of mangosteen (Garcinia mangostana L.) fruit during ripening and after harvest. Postharvest Biology and Technology. 51(3):349-353.

Parakkasi, A. 1990. Ilmu Gizi dan Makanan Ternak Monogastrik. Penerbit Angkasa. Bandung.

Rasyaf, M. 2005. Beternak Ayam Petelur. Cetakan ke XX. Penebar Swadaya. Jakarta.

Toghyani, M., M.Toghyani, A.Gheisari, G. Ghalamkari, and M. Mohammadrezaei 2010. Growth performance, serum biochemistry and blood hematology of broiler chicks fed different levels of black seed (Nigella sativa) and peppermint (Mentha piperita). Livestock Science. 129(1):173-178.

Widjastuti, T. dan E. Sujana. 2009. Pemanfaatan tepung limbah roti dalam ransum ayam broiler dan implikasinya terhadap efisiensi ransum dan IOFC. Prosiding Seminar Nasional Fakultas Peternakan Unpad: 558-562.

Winarti, E. 2017. Pengaruh Penggunaan Roti Afkir sebagai Pengganti Bekatul dan Gaplek dalam Konsentrat Sapi Perah terhadap Produksi Susu. Prosiding Seminar Nasional Teknologi Peternakan dan Veteriner: 147-151. 